\title{
Lower Tithonian and lower Berriasian brachiopods from the Márévár Limestone Formation, Zengővárkony (Mecsek Mountains Hungary), and remarks on their palaeoenvironment
}

\author{
László Bujtor ${ }^{1}\left[\right.$ Richárd Albrecht ${ }^{2}$ (D) Dávid Maróti ${ }^{2} \cdot$ Ákos Miklósy $^{2}$
}

Received: 19 June 2019 / Accepted: 29 January 2020 / Published online: 25 February 2020

(c) The Author(s) 2020

\begin{abstract}
A new collection provided some brachiopods assigned to Lacunosella hoheneggeri, Pygope diphya and P. janitor from the lower Tithonian (Micracanthoceras ponti Zone) and lower Berriasian (Calpionella Zone), and from the limestone succession at Zengővárkony, Mecsek Mountains, Hungary. This is the first taxonomic description and photographic documentation of these fossils. We provide reliable documentation of pygopid brachiopods from the Mecsek Mountains, known since 1880, but previously not described. For the moment, three pygopid brachiopod species are reliably reported from the Mecsek Mountains: Pygope diphya, P. janitor and Pygites diphyioides. The Lacunosella hoheneggeri described herein is the first record of Berriasian rhynchonellide brachiopods from the Mecsek Mountains. The lower Berriasian brachiopods may belong to a normal palaeoenvironment, with the usual size distribution.
\end{abstract}

Keywords Pygope diphya Pygope janitor $\cdot$ Lacunosella hoheneggeri $\cdot$ Micracanthoceras ponti Zone $\cdot$ Calpionella Zone $\cdot$ Palaeoenvironment · Tisza Mega-unit

\section{Introduction}

Berriasian brachiopods are scarce in the Western Tethys. Any new record increases our knowledge. However, Tithonian brachiopods are abundant, especially pygopid ones in the Tethyan faunal realm. After a long static period from the Triassic to the end of the Jurassic (Ager 1993: fig. 10.2), three distinctive genera evolved from the genus Nucleata.

Handling Editor: Mike Reich.

László Bujtor

lbujtor@gamma.ttk.pte.hu

Richárd Albrecht

albrecht.richard.gyula@gmail.com

Dávid Maróti

dave.maroti@gmail.com

Ákos Miklósy

miku1983vii@gmail.com

1 Department of Geology and Meteorology, Faculty of Sciences, Institute of Geography and Earth Sciences, The University of Pécs, 6 Ifjúság útja, Pécs 7624, Hungary

2 Faculty of Sciences, The University of Pécs, 6 Ifjúság útja, Pécs 7624, Hungary
These morphologically characteristic fossils with known stratigraphic distribution have been frequently used for palaeoecological (Vogel 1966; Krobicki 1993; Ager 1994; Lukeneder 2002), and/or palaeobiogeographical analysis (Sandy 1988, 1991; Kázmér 1990, 1993; Somody 1992; Vörös 1993, 1997).

Pygopid brachiopods were first reported from the Mecsek Mountains by Böckh (1880: 17), who carried out geological mapping in that region 1874. He reported Pygope diphya from the Tithonian limestones of the abandoned quarry of Pusztafalu (today referred to as Zengővárkony), but with neither a description nor figure. Later, Vadász (1935: 63) listed occurrences of more pygopid species (Pygope dilatata, P. diphya, P. janitor) from the Tithonian of the Mecsek Mountains, however, again with neither descriptions nor illustrations.

Later authors (Sandy 1988; Kázmér 1990, 1993; Somody 1992; Vörös 1993, 1997) used these works as references for their palaeobiogeographical analyses. Vörös (1997) reexamined the old collection of the Mining and Geological Survey of Hungary (later abbreviated MGSH) and confirmed the presence of Tithonian brachiopods: Fortunella spoliata, Placothyris? carpathica, Pygope diphya, P. cf. janitor, and Zittelina sp., although only a line drawing of a Tithonian 
Pygope diphya from another locality in the Mecsek Mountains was included (Vörös 1997: 107, fig. 53). Bujtor (2006) was the first to publish systematic descriptions and figures of pygopid brachiopods from the Cretaceous of the Mecsek Mountains. Two fragmentary specimens of Pygites diphyoides were reported from the lower Valanginian (Thurmanniceras pertransiens Zone) of Kisújbánya, Mecsek Mountains (Bujtor 2006).

These brachiopods remained without taxonomic descriptions until now, when the present authors revisited their reported localities. Before submitting this paper, we tried to find these pygopid brachiopods in the collection of the MGSH, Budapest. However, the pygopid brachiopods collected by Böckh (1880) and Vadász (1935) from the Mecsek Mountains are currently under revision by Attila Vörös, and were not available; there were no rhynchonellide brachiopods in the collections from the Berriasian of the Mecsek Mountains. The aim of this paper is to report, describe and document the rare Berriasian brachiopods from the Mecsek Mountains that have been known for decades (Böckh 1880, Vadász 1935, Vörös 1997), but only from faunal lists.

\section{Geological setting}

The Mecsek Mountains (Fig. 1) belong to the Tisza MegaUnit (Haas and Péró 2004) as the northernmost unit of the domain, which is considered a microplate (Vörös 1993; Csontos and Vörös 2004). Late Jurassic development of the Mecsek Mountains is characterized by red, nodular, sometimes cherty and thin, ammonitico rosso-type Oxfordian and Kimmeridgian beds (Nagy 1964). In the Tithonian, the first indications of volcanic activity are discontinuous layers and beds of tuff. In the latest Jurassic and Berriasian continental rift type (Harangi 1994), volcanic activity halted carbonate sedimentation and produced an ankaramite-alkaline basaltic paleovolcano (Wein 1961; Császár 2002). The Upper Jurassic_Lower Cretaceous mixed volcano-sedimentary sequence seems to be continuous; however, Nagy (1964) indicated a discontinuity between the uppermost Tithonian and lowermost Berriasian. Contrary to this, a continuous Jurassic/Cretaceous boundary sequence has been suggested by Császár et al. (1990). Based on field observations, the present authors support the opinion of Császár et al. (1990). Related research is going on to define the $\mathrm{J} / \mathrm{K}$ boundary beds in the Mecsek Mountains at Zengóvárkony.

\section{Studied sections}

In the south-eastern part of the Mecsek Mountains in the abandoned quarry at Zengővárkony Böckh (1880) first reported Jurassic beds with pygopid brachiopods (Fig. 2). Böckh also collected ammonites from the abandoned quarry (called by him mészkemencék $=$ lime kilns) that are housed in the collection of MGSH. The lime kilns of Zengővárkony are abandoned today. The small quarries traverse the succession (Fig. 3) from the Oxfordian (Nagy 1964) to the upper Berriasian (Grabowski et al. 2016). An artificial section was excavated during the current study between the lower Tithonian and upper Berriasian (Fig. 4). Some layers are recognized that have yielded pygopid specimens and a specimen of the ammonite Volanoceras volanense that indicates the lower Tithonian Micracanthoceras ponti Zone.

In a NW direction from the artificial section, there is a wall that would have been the quarry wall in the nineteenth century. Some sampling was done in the upper part that revealed a late Berriasian age on magnetostratigraphic sampling (Grabowski et al. 2016). 5-6 meters
Fig. 1 Geographical position of the Mecsek Mountains in Hungary, major tectonic units of Hungary indicated. Map based on Haas and Péró (2004), simplified

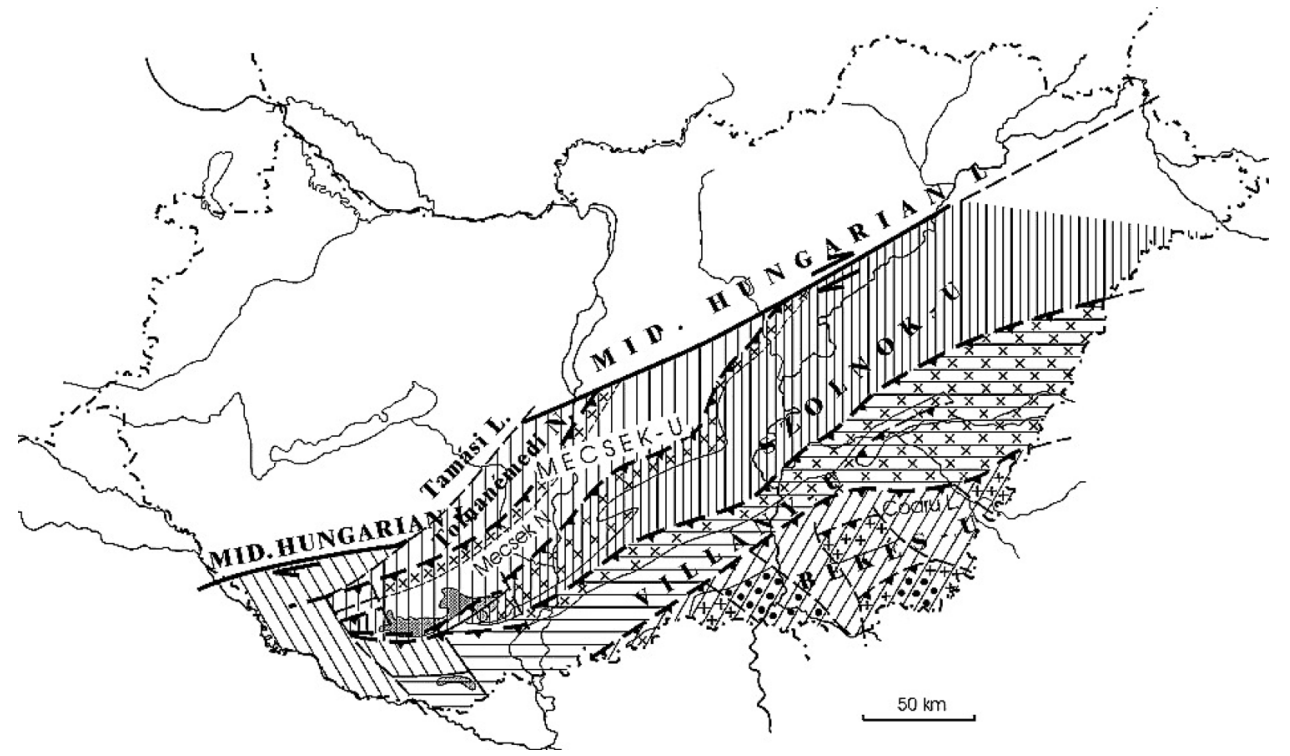


Fig. 2 Locality map. Map shows by asterisks the investigated sections in the Mecsek Mountains, in the vicinity of Zengővárkony. Asterisk in black: lower Berriasian section in the abandoned quarry. Asterisk in grey: lower Tithonian artificial section made during field work of this research in the forest

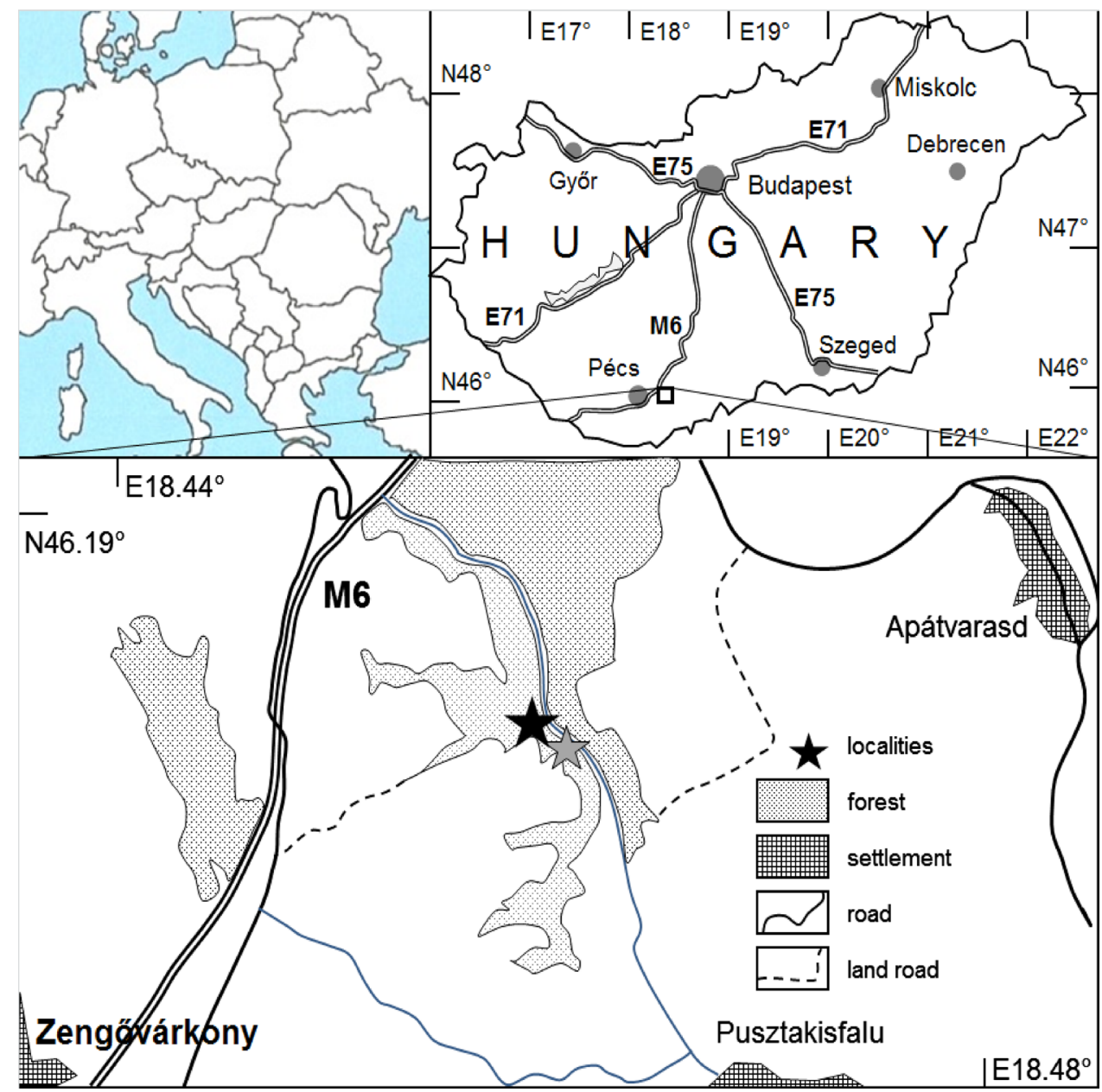

below paleomagnetic sampling points of Grabowski et al. (2016), an early Berriasian section was found that provided other brachiopod specimens (Fig. 5). This part of the section is characterized by massive, pink-red-coloured micritic poorly stratified limestone beds. Thin sections from this bed revealed a rich calpionellid microfauna with Calpionella alpina prevailing that may indicate the lowermost Berriasian.

\section{Materials and methods}

Abbreviations. FO: first occurrence; L: length of the valve; $\mathrm{W}$ : width of the valve; $\mathrm{H}$ : height of the valve; h: length of the perforation on the ventral valve; hl: length of the perforation on surface of the dorsal valve according to Lukeneder (2002). Dimensions are given in mm. Measurements were acquired by a manual caliper. Measurements in brackets refer to estimated data due to poor preservation. The specimens are housed in the Palaeontological Collection of the Hungarian Natural History Museum, Budapest.
Institutional abbreviations. HNHM-Hungarian Natural History Museum, Budapest. Systematics of brachiopods follows the system of Williams et al. (1996).

\section{Systematic palaeontology}

Phylum Brachiopoda Duméril, 1806

Subphylum Rhynchonelliformea Williams, Carlson, Brunton, Holmer, and Popov, 1996

Class Rhynchonellata Williams, Carlson, Brunton, Holmer, and Popov, 1996

Order Rhynchonellida Kuhn, 1949

Superfamily Pugnacoidea Rzhonsnitskaia, 1956

Family Basiliolidae Cooper, 1959

Subfamily Lacunosellinae Smirnova, 1963

Genus Lacunosella Wisniewska, 1932

Type species. Rhynchonella arolica Oppel, 1865. 


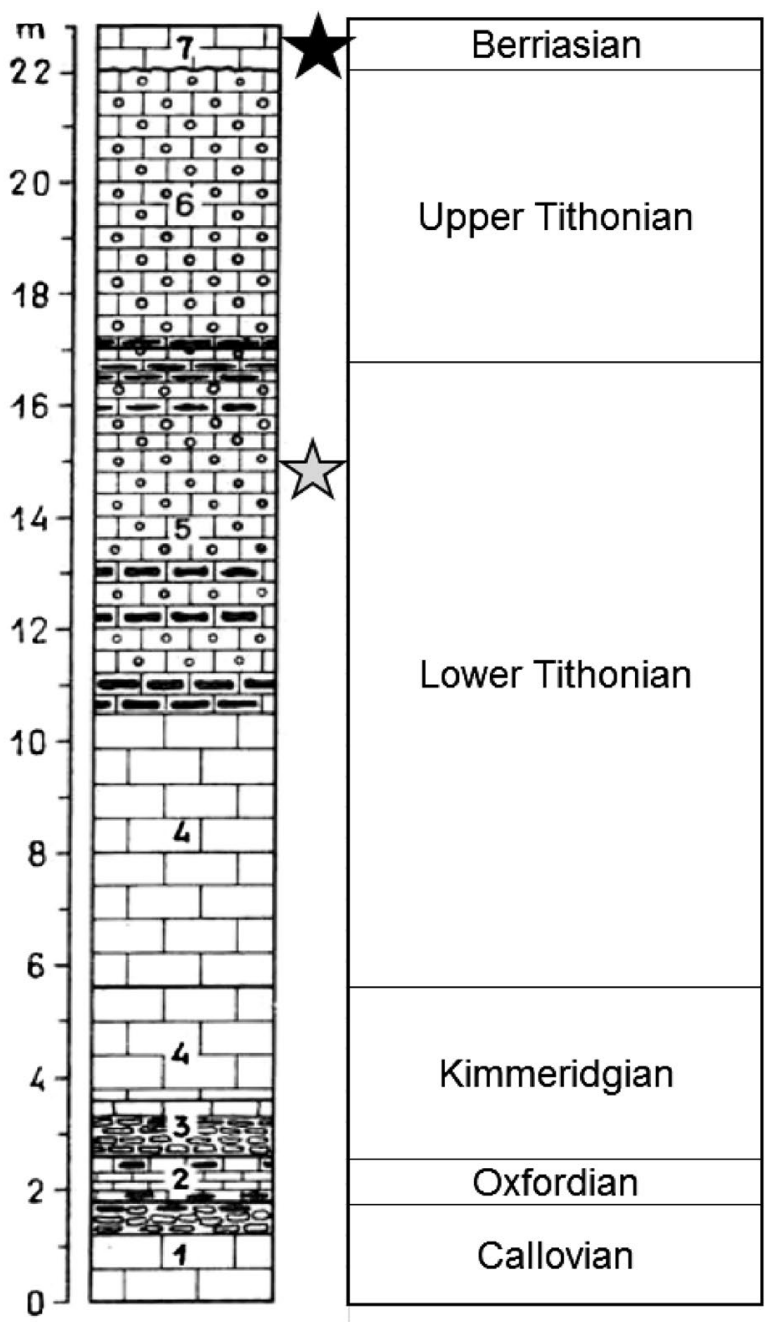

Fig. 3 The upper Jurassic-lower Cretaceous section at Zengóvárkony, Mecsek Mountains, South Hungary. Lithological column after Nagy (1964), simplified. Asterisks indicate the position of the brachiopods collected from the section. Legend: 1: light coloured yellowish-grey thick bedded limestone; 2: thin bedded limestone; 3: marly-clayey, red coloured nodular limestone; 4: light coloured yellowish-grey thick bedded limestone; 5: light coloured yellowish-grey brecciated limestone with flint nodules; 6: yellowish-white brecciated limestone; 7: brownish-yellow clayey limestone

\section{Lacunosella hoheneggeri (Suess, 1858)}

Figure 6a-e

1858 Rhynchonella Hoheneggeri Suess-Suess: p. 56, pl. 6, figs. 13-19.

1870 Rhynchonella Hoheneggeri Suess-Zittel: p. 147, pl. 38, figs. 29-31.

? 1899 Rhynchonella Hoheneggeri Suess-Remeš: p. 229, pl. 8, figs. 1-2.

1977 Lacunosella hoheneggeri (Suess)—Nekvasilová: p. 60, pl. 4, figs. 1-9; pl. 5, figs. 1-5.

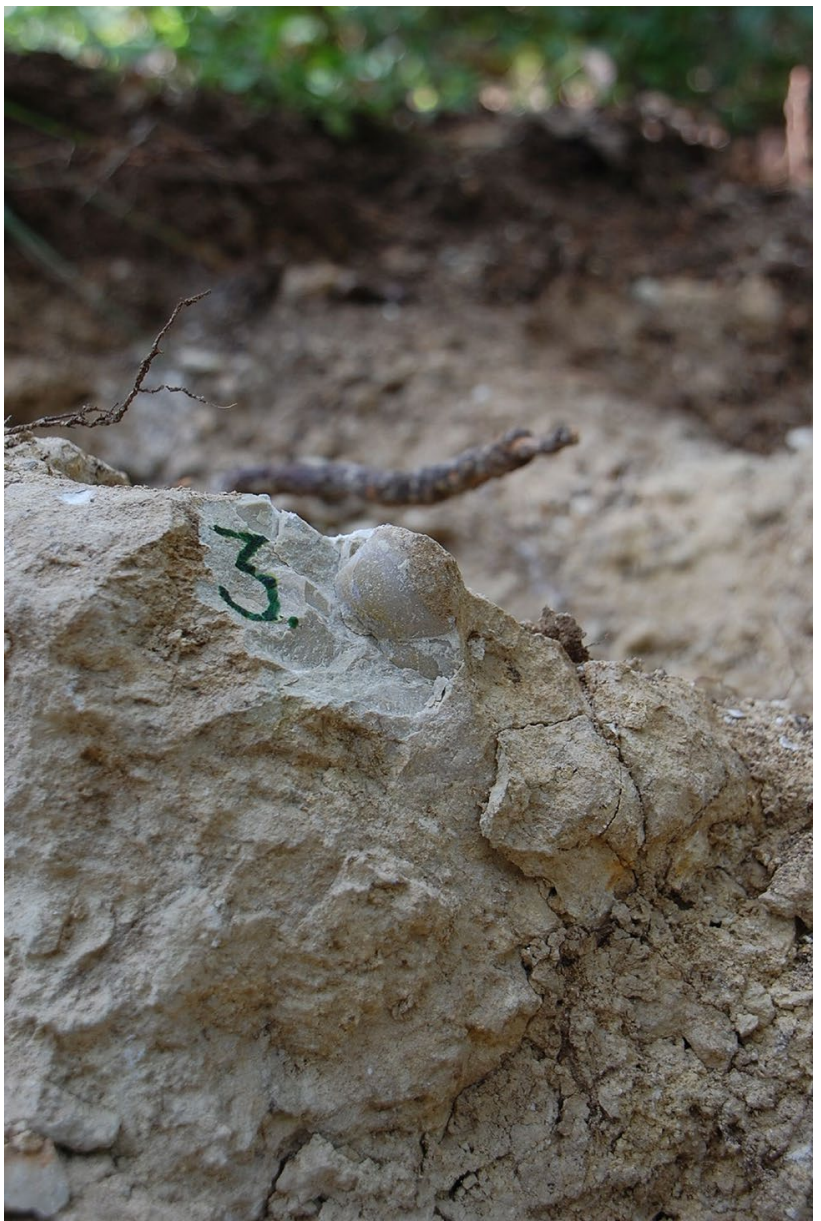

Fig. 4 Pygope diphya (specimen INV 2019.2816) in situ preserved in the lower Tithonian tuffitic limestone beds from an artificial section at Zengővárkony lime kilns. Coordinates: $46.1841^{\circ} \mathrm{N} ; 18.4584^{\circ} \mathrm{E}$

1979 Lacunosella hoheneggeri (Suess)—Barczyk: p. 55, pl. 2, figs. 4-5.

1996 Lacunosella hoheneggeri (Suess)-Krobicki: fig. 7.5.

1996 Lacunosella hoheneggeri (Suess)—Krobicki and Wierzbowski: fig. 4.3a-c.

2006 Lacunosella hoheneggeri (Suess)—Bujtor: p. 119, figs. 4-6, 7.1-4.

Studied material. One well preserved, partly decorticated specimen from limestone bed, Calpionella Zone, Lower Berriasian, Zengővárkony Mészkemencék section.

\section{Dimensions.}

\begin{tabular}{llll}
\hline Specimen no. & $L$ & $W$ & $H$ \\
\hline INV 2019.2814 & 15.2 & 16.0 & 11.9
\end{tabular}




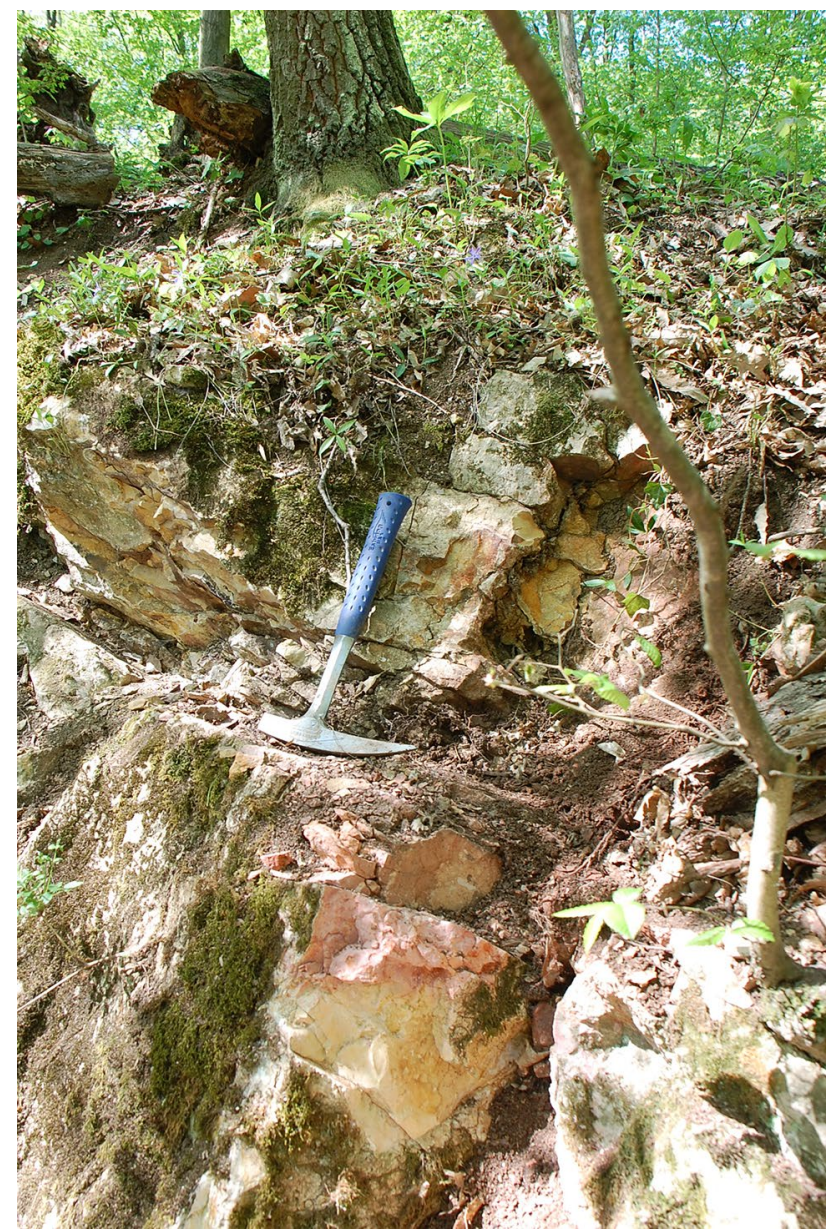

Fig. 5 Lower Berriasian, massive, pink coloured micritic limestone beds in the NW quarry wall of the Zengővárkony lime kilns section. Hammer points to the bed from where the Lacunosella hoheneggeri and Pygope janitor were collected. Coordinates: $46.1848^{\circ} \mathrm{N}$; $18.4564^{\circ} \mathrm{E}$
Description. External characters: shell inflated wider than longer Lacunosella. Dorsal valve more inflated than ventral valve. Umbo small, erect, foramen not seen. Commissure uniplicate. Shell ornamented with strong primary ribs originated from the umbo. There are eight primary ribs on ventral and seven on dorsal valve. Fine growth lines and fine secondary ribs are only on the ventral valve. These intercalatory secondary ribs are not seen on the internal mould. Nekvasilová (1977: 60-68) gave a detailed diagnosis, which is accepted and followed here.

Internal characters-As only one specimen was recovered, serial sections were not prepared.

Remarks. Although this species has extreme variability (Nekvasilová 1977: 67), the specimens of Remeš (1899: pl. 8 , figs. 1, 2) may fall outside the variability (lack of strong ribs, not inflated shell, etc.). The dimensions of the present specimen (length and width) conform to the average dimensions taken from 1100 specimens (Nekvasilová 1977). Bujtor (2006) reported it also from Zengővárkony but from younger (upper Valanginian-lower Hauterivian) sediments. The younger population of L. hoheneggeri from the same locality presented a significant average size increase (Bujtor 2007: 192, fig. 4) of mean dimensions compared to the material from the type locality in Štramberk, Czech Republic (Nekvasilová 1977). However, the dimensions of the present specimen fall into the range of the Štramberk population of Nekvasilová (1977). The present specimen is most similar to the specimen of Barczyk (1979: pl. 2, fig. 4).

Stratigraphic and geographic distribution. Tithonian to Valanginian of SE France, Štramberk (Czech Republic), Hungary, Pieniny Klippen Belt (Poland), and the Ukrainian Carpathians.
Fig. 6 a-e Lacunosella hoheneggeri (Suess 1858) lower Berriasian, Zengővárkony, Mecsek Mountains, Hungary; specimen INV 2019.2814. a Dorsal view; $\mathbf{b}$ ventral valve; $\mathbf{c}$ posterior view; $\mathbf{d}$ lateral view; $\mathbf{e}$ anterior view
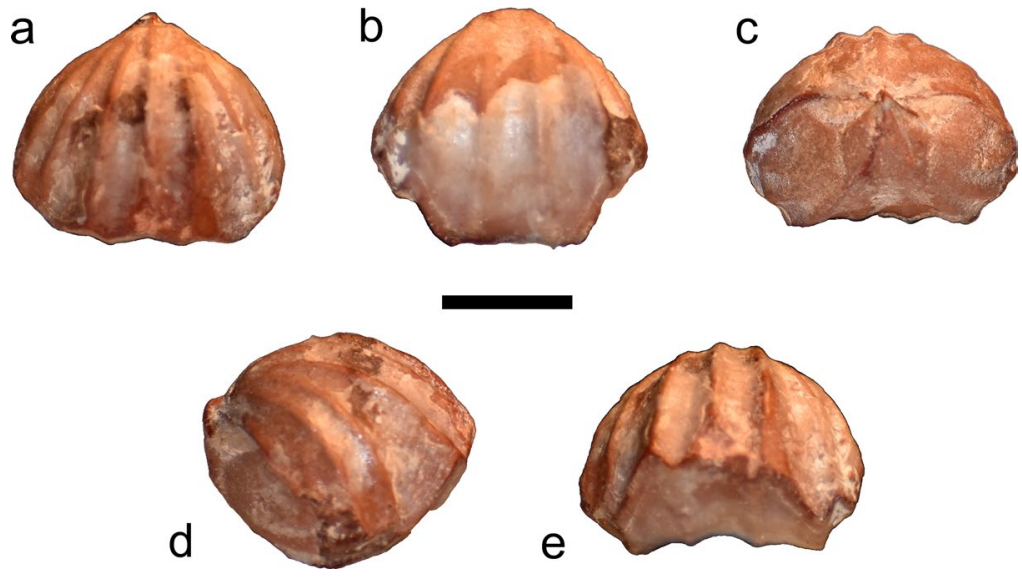
Order Terebratulida Waagen, 1883

Suborder Terebratulidina Waagen, 1883

Superfamily Discolioidea Fischer and Oehlert, 1891

Family Pygopidae Muir-Wood, 1965

Subfamily Pygopinae Muir-Wood, 1965

Genus Pygope Link, 1830

Type species. Terebratula antinomia Catullo, 1827.

Pygope diphya (von Buch, 1835)

Figure $7 \mathrm{a}-\mathrm{c}$

1610 Concha diphya-Colonna: p. 388, pl. XXXVI.

1835 Terebratula diphya Fabio Colonna-von Buch: p. 108, pl. I, fig. 12.

1870 Terebratula diphya Fabio Colonna-Zittel: p. 126, pl. 13, figs. $1-10$.

1880 Terebratula diphya F. C.—Böckh: p. 17. [in lit.]

1935 Pygope diphya Cat. sp._-Vadász: p. 63. [in lit.]

1948 Terebratula (Pygope) diphya Col._-Trauth: p. 211. [in lit.]

1959 Pygope diphya (Col.)—Kotanski and Radwanski: pl. LVI. fig. 2.

1962 Pygope diphya Fabius Columna-Jarre: p. 48, pl., fig. 5; pl. D, figs. 1-3; pl. E, fig. 1.

1963 Pygope diphya (Columna)—Thieuloy: p. 284, pl. II, fig. $1 \mathrm{a}-\mathrm{c}$.

1972 Pygope diphya (Colonna)_Barczyk: p. 509, pl. 1, figs. 2-3; pl. 4, figs. 1-3; text-fig. 1.

1981 Pygope diphya (von Buch)—Dieni and Middlemiss: p. 29, pl. I, figs. 1-4.

1992 Pygope diphya (von Buch)—Somody: p. 114. [in lit.]

1997 Pygope diphya (Buch)_Vörös: p. 107, fig. 53.

2007 Pygope diphya (Buch)__Vörös and Dulai: pl. III, fig. $29 \mathrm{a}-\mathrm{b}$.

2016 Pygope diphya (Buch)—Sulser: fig. 8t.

Material. Two badly preserved, fragmentary, partly decorticated internal moulds from limestone bed, Micracanthoceras ponti Zone (lower Tithonian), Zengővárkony Mészkemencék section.
Dimensions.

\begin{tabular}{llllll}
\hline Specimen no. & $L$ & $W$ & $H$ & $h$ & hl \\
\hline INV 2019.2815 & 50.6 & 55.3 & 23.9 & 6 & 16 \\
INV 2019.2816 & 44 & $(56)$ & $(23)$ & - & 17 \\
\hline
\end{tabular}

Description. External characters: Shell large, adult, triangular shape, biconvex, laterally not inflated with elongated, teardrop shape foramen on the brachial valve placed close to the umbo. Ventral valve has a narrow ridge from the umbo to the perforation. Maximum width of the ridge is $5.5 \mathrm{~mm}$, maximum height $2 \mathrm{~mm}$. The internal moulds are partly covered by shell with a thickness of $0.3-0.5 \mathrm{~mm}$. Lateral commissure is not seen, anterior commissure is straight. Umbo is big, erect, oval shaped. Both valves show fine growth lines throughout from the umbo to the anterior commissure. Where it is not covered by shell remains, fine and thin imprints of vascular myarium channels are preserved on the right side of the dorsal valve internal mould (specimen INV 2019.2815).

Internal characters-As only one complete specimen was recovered, serial sections were not prepared.

Remarks. Böckh (1880) noted that preservation is bad but he collected many specimens. We have only collected two specimens but with poor preservation. The present specimens agree most closely with the specimen of Barczyk (1972: pl. 4, fig. 2a) and Sulser (2016: fig. 8t) with the same narrow and elongated foramen. It differs from the specimen of Vörös and Dulai (2007) with its narrower and elongated foramen, less inflated ventral valve and less developed umbo.

The authorship of $P$. diphya is variously interpreted. Authors refer to Catullo or von Buch as the original author of the species; however in his original work, von Buch (1835) clearly referred to Fabio Colonna (cf. Dollfuss and Dautzenberg 1932: 312). Notwithstanding, according to Art. 3.2. of the International Code of Zoological Nomenclature " no name published before 1 January 1758 enters zoological nomenclature but information published before that day may be used". Therefore, von Buch must be credited as the author of the species; however, Fabio Colonna (or Fabius Columnae) could be indicated. We strongly suggest keeping
Fig. 7 a-c Pygope diphya (Buch 1835) lower Tithonian Micracanthoceras ponti Zone, Zengővárkony, Mecsek Mountains, Hungary; specimen INV 2019.2816. a Dorsal view; b ventral view; c anterior view
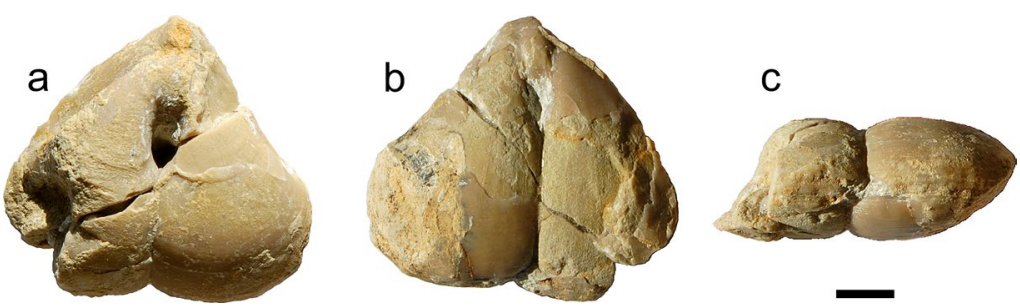
Fabio Colonna in taxonomic descriptions due to his pioneering work in natural sciences.

Stratigraphic and geographic distribution. Stratigraphic distribution: FO of $P$. diphya is at the base of the lower Tithonian and it disappears by the end of the Berriasian (Dieni and Middlemiss 1981). It occurs in the western part of the Tethys, most commonly along the northern margin; however, it also appears along the southern margin of the Tethys, in Morocco (Somody 1992).

Pygope janitor (Pictet, 1867)

Figure $8 \mathrm{a}-\mathrm{c}$

1867 Terebratula janitor Pictet-Pictet: p. 161, pl. 29, figs. 4-6, pl. 30.

1873 Terebratula janitor Pictet-Neumayr: pl. XLIII, fig. 8.

1890 Pygope janitor Pictet-Toucas: p. 585, pl. XIV, fig. $8 \mathrm{a}-\mathrm{b}$.

1899 Terebratula janitor Pictet-Remeš: p. 220, text-fig. 5A-D.

1935 Pygope janitor Pict._Vadász: p. 63. [in lit.]

1962 Pygope janitor Pictet-Jarre: p. 38, pl. B, figs. 2-5; pl. C, figs. 1-8; text-fig. 4.

1972 Pygope janitor (Pictet)-Barczyk: p. 511, pl. 2, figs. 1-2; pl. 3, figs. 1-2.

1973 Pygope janitor Pictet-Preda: pl. 10, fig. 12.

1981 Pygope janitor (Pictet)_Dieni and Middlemiss: p. 36, pl. IV, fig. 2.

1993 Pygope janitor (Pictet) -Inesta-Alcoela: p. 14, pl. II, fig. $3 \mathrm{a}-\mathrm{d}$.

1994 Pygope janitor (Pictet)—Főzy et al.: pl. 2, figs. 17-18.

1994 Pygope janitor (Pictet)-Vašíček et al.: pl. 13, figs. 13-14.

1996 Pygope janitor (Pictet)_Krobicki and Wierzbowski: fig. 4.5a.

1996 Pygope janitor-Michalík: figs. 2, 3.5-6, 3.8, 3.10-12.

1997 Pygope janitor (Pictet)_Benzaggagh and Atrops: pl. 5, fig. 4.

2005 Pygope janitor (Pictet)—Enay et al.: fig. 4.8a-b.
2005 Pygope janitor (Pictet)-Harper et al.: p. 221, fig. 2 Q. 2013 Pygope janitor (Pictet)—Dirksen et al.: pl.1, figs. 2-5. 2016 Pygope janitor (Pictet)_Sulser: fig. 8u.

Material. One, poorly preserved, broken and fragmentary, partly decorticated specimen from limestone bed, Calpionella Zone (Lower Berriasian), Zengővárkony, Mészkemencék section.

Dimensions.

\begin{tabular}{llllll}
\hline Specimen no. & $L$ & $W$ & $H$ & $h$ & hl \\
\hline INV 2019.2817 & 51 & 53 & 31 & $(15)$ & 29 \\
\hline
\end{tabular}

Description. External characters: Large sized, adult, biconvex and inflated, triangular shape shell with large, centrally placed perforation. The wall of the central perforation is vertical towards the flanks and rounded towards the umbo. Lateral commissure slightly sinusoidal; anterior commissure straight. Pedicle opening and umbo not preserved. Fine growth lines preserved throughout both flanks. Shell remnants around the lateral flanks of the central perforation, are $0.5-0.7 \mathrm{~mm}$ thick. Pronounced, branching vasculum myarium is preserved on the internal cast of the left dorsal valve. Maximum width of the canal $1.4 \mathrm{~mm}$. Regarding intraspecific variability, the present specimen conforms with the second variation of Jarre (1962: 40, pl. B, fig. 3) with triangular shape and touching flanks.

Internal characters-As only one specimen was recovered serial sections were not prepared.

Remarks. The open perforation may refer to Pygites diphyoides (d'Orbigny 1847) but the lack of the pronounced ridge with sulcus of the dorsal valve (cf. Middlemiss 1978: pl. 15, fig. $1 \mathrm{a}-\mathrm{b}$ ) unequivocally refers to the species janitor. Other similarities (big central perforation, triangular shape) are towards Pygites magomaevi; however, that species lacks a biconvex shape, while the present specimen has a biconvex shape. It differs from the specimen of Toucas (1890: pl. XIV,
Fig. 8 a-c Pygope janitor (Pictet 1867) lower Berriasian, Zengővárkony, Mecsek Mountains, Hungary; specimen INV 2019.2817. a Dorsal view; b lateral view; c ventral view
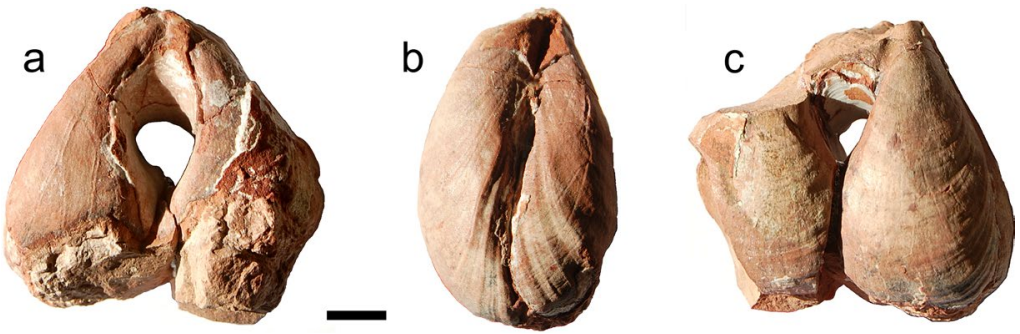
fig. 8a-b) where the latter represents a juvenile stage where the flanks are not touching each other. Vašíček et al. (1994) described a specimen from the Hauterivian with an elongated perforation. The present specimens are most similar to the specimen of Pictet (1867: pl. 30, fig. 3A-B), Remeš (1899: text-fig. 5D), Michalík (1996: fig. 3.8), Benzaggagh and Atrops (1997: pl. 5, fig. 4), and Enay et al. (2005) with its big, central perforation, touching flanks, triangular shape and convex, inflated dorsal and ventral valves. The most remarkable feature of the present specimen is its large size and inflated biconvex lateral profile, which is not mentioned in the literature. Due to the fragmentary and broken preservation, the original dimensions of the specimen were bigger and the inflated flanks (T: $31 \mathrm{~mm}$ ) may refer to a special local environment.

Stratigraphic and geographic distribution. Stratigraphic distribution: P. janitor FO is most probably in the Kimmeridgian and it disappears in the middle Barremian (Dieni and Middlemiss 1981). It has wide geographic distribution mainly in the western part of the Tethyan Realm with scarce occurrences in the Boreal Realm (East Greenland: Harper et al. 2005).

\section{Discussion}

Pygopid brachiopods are frequently used for palaeobiogeographical analysis. Kázmér $(1990,1993)$ proposed that the pairs of Pygope catulloi and P. diphya inhabited the nutrientpoor southern margin of Tethys, while $P$. janitor and Pygites diphyoides with a large central perforation inhabited the nutrient-rich northern margin of the Tethys. This assumption is rejected by Michalík (1996) on the basis that brachiopod distribution data did not support this pattern. However, later research may support this idea (Lukeneder 2002). Pygopids were also used as the marker ('Tethyan index' cf. Michalík 1992) of the Tethys; however, their presence in the Boreal Realm (Harper et al. 2005) did not fit into this assumption. Hence, it must be noted here that Ager and Walley (1977) considered a geographic range extension via the opening of the Atlantic Ocean. But other factors may interact, too. A Gulf Stream-type circulation may also have contributed to their extra-Tethyan distribution (Ager 1986; Sandy 1991).

Regarding the paleoecology of this group, it is also disputed. Although they are significant elements of the Tethyan basinal faunas (Ager 1976), their distribution was not only controlled by bathymetry and temperature (Michalík 1992), but by ocean currents, too (Ager 1994). Traditionally, pygopids are interpreted as deep-water organisms (Ager 1965, 1976). Today, pygopid brachiopods are rather considered as indicative of colder than warmer waters with eurybathic character. It is also suggested that pygopid brachiopods also occupy shallow water environments over seamounts (Ager 1993). On the other hand, in faunal assemblages, the increasing percentage of pygopids suggests deeper environments (Golonka and Krobicki 2001).

It is important to emphasize that in the Mecsek Mountains (but also in the Mecsek Tectonic unit) during the Berriasian volcanic activity intensified, Berriasian-Valanginian age pillow lavas are reported from the sequence, therefore the ocean floor was not quiescent, and undisturbed. It is remarkable, that beside the benthic brachiopods only nektonic animal remains (ammonites and calpionellids) and some microfossils (foraminifers) are recorded from the Tithonian-Berriasian beds in the Mecsek Mountains.

On the other hand, it is worth mentioning that the present specimen of Lacunosella hoheneggeri is remarkably smaller than those of the late Valanginian-early Hauterivian iron ore-related brachiopod fauna that is dominated by L. hoheneggeri (Bujtor 2006, 2007) from the same locality. But this is not surprising. The average mean dimensions of L. hoheneggeri are in line with the dimensions of the present specimen: Average L: 15.7 and average W: $16.3 \mathrm{~mm}$ (Bujtor 2007; Nekvasilová 1977). The dimensions of the present specimen fall into this range (see: Dimensions). This is further evidence that in normal conditions (e.g., at type locality of L. hoheneggeri in Štramberk, Czech Republic and the lower Berriasian at Zengóvárkony), the length and width of this species is around $16 \mathrm{~mm}$; while under special, nutrientrich conditions, it remarkably shifts to larger dimensions due to special ecological conditions (Bujtor and Vörös in press).

\section{Conclusion}

The first description and publication of pygopid brachiopods based on a new collection from the Mecsek Mountains (South Hungary) provides a solid foundation for any further palaeobiogeographic analysis, which has been based only on faunal lists during the past 140 years. The new field collection supported the presence of two pygopid species (Pygope diphya, P. janitor) in the region from where earlier researchers (Böckh 1880; Vadász 1935) quoted the presence of three pygopid species, which represent the Tithonian and the Berriasian. Based on previous (Bujtor 2006) and current research presented herein, three pygopid species are confirmed from the Upper Jurassic and Lower Cretaceous succession of the Mecsek Mountains: Pygope diphya, $P$. janitor and Pygites diphyoides. The new occurrence of Lacunosella hoheneggeri and its dimensions refer to normal ecological conditions as in its type locality in Štramberk, Czech Republic.

Acknowledgements Open access funding provided by University of Pécs (PTE). This research was supported by the project 99 öu02 of 
the Österreichische-Ungarische Aktion Gesellschaft (Osztrák-Magyar Akció Alapítvány). The authors are thankful to the owner of the land, Mr. Ferenc Vogl for his kind permission to enter and collect on his land. The authors are indebted to Attila Vörös for his careful comments and suggestions on the early version of this paper. Our special thanks due to the reviewers, Donald A.B. MacFarlan (New Zealand), and Michael R. Sandy (University of Dayton, USA), Mike Reich (Editor-in-Chief) for their critical remarks and suggestions as well as correcting our English which significantly improved the quality of this paper.

Open Access This article is licensed under a Creative Commons Attribution 4.0 International License, which permits use, sharing, adaptation, distribution and reproduction in any medium or format, as long as you give appropriate credit to the original author(s) and the source, provide a link to the Creative Commons licence, and indicate if changes were made. The images or other third party material in this article are included in the article's Creative Commons licence, unless indicated otherwise in a credit line to the material. If material is not included in the article's Creative Commons licence and your intended use is not permitted by statutory regulation or exceeds the permitted use, you will need to obtain permission directly from the copyright holder. To view a copy of this licence, visit http://creativecommons.org/licenses/by/4.0/.

\section{References}

Ager, D.V. 1965. The adaptations of Mesozoic brachiopods to different environments. Palaeogeography, Palaeoclimatology, Palaeoecology 1: 143-172.

Ager, D.V. 1976. The nature of the fossil record. Proceedings of the Geologists' Association 87: 131-160.

Ager, D.V. 1986. Migrating fossils, moving plates and an expanding Earth. Modern Geology 10: 377-390.

Ager, D.V. 1993. The new catastrophism, 1-252. Cambridge: Cambridge University Press.

Ager, D.V. 1994. Brachiopod stratigraphy in the Jurassic. Geobios 17: $57-68$.

Ager, D.V., and C.D. Walley. 1977. Mesozoic brachiopod migrations and the opening of the North Atlantic. Palaeogeography, Palaeoclimatology, Palaeoecology 21(2): 85-99.

Barczyk, W. 1972. Some representatives of the family Pygopidae (Brachiopoda) from the Tithonian of the Pieniny Klippen Belt. Acta Geologica Polonica 22(3): 507-513.

Barczyk, W. 1979. Brachiopods from the Jurassic/Cretaceous boundary of Rogoznik and Czorsztyn in the Pieniny Klippen Belt. Acta Geologica Polonica 29(2): 207-214.

Benzaggagh, M., and F. Atrops. 1997. Stratigraphie et association de faune d'ammonites des zones du Kimméridgien, Tithonien et Berriasien basal dans le Prérif interne (Rif, Maroc). Newsletters on Stratigraphy 35(3): 127-163.

Böckh, J. 1880. Adatok a Mecsekhegység és dombvidéke jurakorbeli lerakodásainak ismeretéhez. I. Stratigraphiai rész. Értekezések a Természettudományok Köréböl 10(10): 3-50.

Buch, L. von. 1835. Über Terebrateln, mit einem Versuch, sie zu classificiren und zu beschreiben. Abhandlungen der Königlichen Akademie der Wissenschaften zu Berlin 1833: 21-144.

Bujtor, L. 2006. Early Valanginian brachiopods from the Mecsek Mts. (southern Hungary) and their palaeobiogeographical significance. Neues Jahrbuch für Geologie und Paläontologie, Abhandlungen 241(1): 111-152.

Bujtor, L. 2007. A unique Valanginian paleoenvironment at an iron ore deposit near Zengővárkony (Mecsek Mts, South Hungary), and a possible genetic model. Central European Geology 50(3): 183-198.
Bujtor, L., and A. Vörös. 2019. New Kingenoid (Terebratellidina) brachiopods with larger body sizes from the Early Cretaceous of Zengővárkony (Mecsek Mountains, Hungary). Journal of Paleontology. https://doi.org/10.1017/jpa2019.94.

Catullo, T.A. 1827. Saggio di Zoologia fossile, 1-348. Padova: Dalla Tipografia del Seminario.

Colonna, F. 1610. Minus cognitarum stirpium aliquot ac etiam rariorum nostro coelo orientium. Ekphrasis. Item de aquatilibus, aliisque animalibus quibusdam paucis libellus, 1-530. Roma: Guglielmo Facciottus.

Cooper, G.A. 1959. Genera of Tertiary and recent rhynchonelloid brachiopods. Smithsonian Miscellaneous Collections 139(5): $1-90$.

Császár, G. 2002. Urgon formations in Hungary with special reference to the Eastern Alps, the Western Carpathians and the Apuseni Mountains. Geologica Hungarica series Geologica 25: 1-209.

Császár, G., A. Galácz, J. Haas, M. Kázmér, S. Kovács, A. Nagymarosy, K. Szentgyörgyi, and A. Vörös. 1990. Paleogeography of the Pannonian Basin. In Evolution of the northern margin of Tethys, vol. III. eds. M. Rakús, J. Dercourt, and A.E.M. Nairn. Mémoires de la Société Géologique de France, Nouvelle Série 154: 63-89.

Csontos, L., and A. Vörös. 2004. Mesozoic plate tectonic reconstruction of the Carpathian region. Palaeogeography, Palaeoclimatology, Palaeoecology 210: 1-56.

Dieni, I., and F.A. Middlemiss. 1981. Pygopid brachiopods from the Venetian Alps. Bollettino della Societá Paleontologica Italiana 20(1): 19-48.

Dirksen E.O, I.N Ruzaeva, V.N Komarov. 2013. Pygopids (Terebratulida, Brachiopoda) of the Crimean Mountains in the collection of the MGPI-RSGPU Geological-Palaeontological Museum. In Palaeontological and geological monuments and collections: significance of museums for their study and preservation. Collection of scientific articles, 85-87. Kungur: Kungur HistoricalArchitecture and Art Museum / Geological Institute RAN. (in Russian).

Dollfuss, G., and Ph Dautzenberg. 1932. Les mollusques de Fabius Columna. Journal de Conchyliologie 76: 283-333.

Duméril, A.M.C. 1806. Zoologie analytique, ou méthode naturelle de classification des animaux, rendue plus facile à l'aide de tableaux synoptiques, $\mathrm{i}-\mathrm{xxxiii}+1-344$. Paris: Allais.

Énay, R., P. Hantzpergue, M. Soussi, and C. Mangold. 2005. La limite Kimméridgien-Tithonien et l'âge des formations du Jurassique supérieur de la Dorsale tunisienne, comparaisons avec l'Algérie et Sicily. Géobios 38: 437-450.

Fischer, P., and D.-P. Oehlert. 1891. Brachiopodes. In Expéditions scientifiques du 'Travailleur' et du 'Talisman' (1880-1883), ed. E. Milne-Edwards, 1-140. Paris: Masson et Cie.

Főzy, I., M. Kázmér, and I. Szente. 1994. A unique Lower Tithonian fauna in the Gerecse Mts, Hungary. Palaeopelagos Special Publications 1: 155-165.

Golonka, J., and M. Krobicki. 2001. Upwelling regime in the Carpathian Tethys: a Jurassic-Cretaceous palaeogeographic and paleoclimatic perspective. Geological Quarterly 45(1): 15-32.

Grabowski, J., G. Császár, E. Márton, A. Pszczólkowski, and D. Lodowski. 2016. Upper Berriasian Magnetostratigraphy in the Mészkemence Section, Mecsek Mts (southern Hungary). Publications of the Institute of Geophysics, Polish Academy of Sciences 423(C112): 45-46.

Haas, J., and C.S. Péró. 2004. Mesozoic evolution of the Tisza Megaunit. International Journal of Earth Sciences 93(2): 297-313.

Harangi, Sz. 1994. Geochemistry and petrogenesis of the Early Cretaceous continental rift-type volcanic rocks of the Mecsek Mountains: South Hungary. Lithos 33: 303-321.

Harper, D.A.T., P. Alsen, E.F. Owen, and M.R. Sandy. 2005. Early Cretaceous brachiopods from North-East Greenland: biofacies 
and biogeography. Bulletin of the Geological Society of Denmark 52: $213-225$.

International Code of Zoological Nomenclature. 1999. The International Trust for Zoological Nomenclature. https://www.iczn.org/ the-code/.

Iñesta-Alcolea, M. 1993. El Jurásico del Cerro de la Mola y su fauna de braquiópodos (Novelda, Alicante). Cidaris 2(3): 4-19.

Jarre, P. 1962. Révision du genre Pygope. Géologie Alpine 38: 23-120.

Kázmér, M. 1990. Tithonian-Neocomian palaeogeography of Pygopidae (Brachiopoda) in the Alpine-Carpathian region. Általános Földtani Szemle 25: 327-335.

Kázmér, M. 1993. Pygopid brachiopods and Tethyan margins. In Mesozoic brachiopods of Alpine Europe, eds. J. Pálfy and A. Vörös, 59-68. Budapest: Hungarian Geological Society.

Kotanski, Z., and A. Radwanski. 1959. High-Tatric Tithonian in the Osobita region, its fauna with Pygope diphya and products of volcanoes. Acta Geologica Polonica 9: 519-534.

Krobicki, M. 1993. Tithonian-Berriasian brachiopods in the Niedzica Succession of the Pieniny Klippen Belt (Polish Carpathians): Paleoecological and paleobiogeographical implications. In Mesozoic brachiopods of Alpine Europe, eds. J. Pálfy, and A. Vörös A, 69-77. Budapest: Hungarian Geological Society.

Krobicki, M. 1996. Valanginian (Early Cretaceous) brachiopods of the Spisz Limestone Formation, Pieniny Klippen Belt, Polish Carpathians: their stratigraphic ranges and palaeoenvironment. Studia Geologica Polonica 109: 87-102.

Krobicki, M., and A. Wierzbowski. 1996. New data on stratigraphy of the Spisz Limestone Formation (Valanginian) and the brachiopod succession in the lowermost Cretaceous of the Pieniny Klippen Belt, Carpathians, Poland. Studia Geologica Polonica 109: 53-66.

Kuhn, O. 1949. Lehrbuch der Paläozoologie, v + 1-326. Stuttgart: E. Schweizerbart.

Link, H.F. 1830. Handbuch der physikalischen Erdbeschreibung, 2(1), 1-498. Berlin: Dummler.

Lukeneder, A. 2002. Shell accumulation of the brachiopod Pygope catulloi Pictet, 1867 (Lower Valanginian; Northern Calcareous Alps, Upper Austria): palaeoecological implications. Annalen des Naturhistorisches Museums in Wien (Serie A) 103: 143-159.

Michalík, J. 1992. The structure and distribution of the European Cretaceous brachiopod assemblages with emphasis on the Tethyan fauna. New Aspects on Tethyan Cretaceous Fossil Assemblages. Schriftenreihe der Erdwissenschaftlichen Kommissionen der Österreischischen Akademie der Wissenschaften 9: 57-74.

Michalík, J. 1996. Functional morphology_paleoecology of pygopid brachiopods from the Western Carpathian Mesozoic, In Brachiopods. Proceedings of the Third International Brachiopod Congress. eds. P. Copper, and J. Jin, 175-178. Rotterdam: A.A. Balkema Publishers.

Middlemiss, F.A. 1978. The genus Platythyris (Brachiopoda) and its relationship to Pygopidae. Paläontologische Zeitschrift 52(1-2): 28-46.

Muir-Wood, H.M. 1965. Mesozoic and Cenozoic Terebratulidina. In Treatise on Invertebrate Paleontology, Part H, Brachiopoda. ed. R.C. Moore, 762-816. New York, N.Y.: Geological Society of America and Lawrence, Kans.: University of Kansas Press.

Nagy, I. 1964. A Zengővárkonynál feltárt malm rétegösszlet mikrobiofácies-vizsgálata. Magyar Állami Földtani Intézet Évi Jelentése az 1961. évröl I: 97-108.

Nekvasilová, O. 1977. Rhynchonellida (Brachiopoda) from the Lower Cretaceous of Štramberk (Czechoslovakia). Sborník geologických věd (Paleontologie) 19: 45-77.

Oppel, A. 1865. Geognostische Studien in dem Ardèche Département. Paläontologische Mittheilungen aus dem Museum des Königlich Bayerischen Staates 1: 305-322.
d'Orbigny, A. 1847. Paléontologie francaise. Terrains crétacés. Cinquiéme partie: Mollusques Brachiopodes, 1-390. Paris: Chez Arthus Bertrand.

Pictet, F.-J. 1867. Mélanges Paléontologiques, Vol. 3: Études monographique des térébratules du groupe de la T. Diphya. Appendice: Note sur le gisement dans l'Empire d'Autriche, 133-204. Genève: Imprimerie Ramboz et Schuchardt.

Preda, I. 1973. Variaţiile de facies si biostratigrafia jurasicului superior din Munţii Haghimas. Studii si Cercetari de Geologie-Geografie Biologie seria Geologie-Geografie 2: 11-22.

Remeš, M. 1899. Beiträge zur Kentniss der Brachiopoden des Stramberger Tithon. Jahrbuch der kaiserlich und königlichen geologischen Reichsanstalt 49(2): 213-234.

Rzhonsnitskaia, M.A. 1956. Systematization of Rhynchonellida. In Resumenes de los Trabajos Presentados. E. Guzmán and others, eds. International Geological Congress, Mexico, Report 20: 125-126.

Sandy, M.R. 1988. Tithonian Brachiopoda. In Evolution of the Northern Margin of Tethys, vol. I. eds. M. Rakus, J. Dercourt, and A.E.M. Nairn. Mémoires de la Société Géologique de France (Nouvelle Série) 154: 71-74.

Sandy, M.R. 1991. Aspects of Middle-Late Jurassic-Cretaceous Tethyan brachiopod biogeography in relation to tectonic and paleoceanographic developments. Palaeogeography, Palaeoclimatology, Palaeoecology 87: 137-154.

Smirnova, T.N. 1963. Rannemelovye brakhiopody Kryma i severnogo Kavkaza. [Early Cretaceous brachiopods of the Crimea and northern Caucasus, 1-20. Moscow: Izdatel'stvo Moskovskogo Universiteta. (Unpublished $\mathrm{PhD}$ thesis).

Somody, Á. 1992. Paleobiogeographic relationships of the Early Cretaceous brachiopods of the Bakony Mts. in the Alpine-Carpathian region. Discussiones Palaeontologicae 38: 107-119.

Suess, E. 1858-1859. Die Brachiopoden der Stramberger Schichten. Beiträge zur Palaeontologie und Geologie Oesterreich-Ungarns und des Orients 1(1-2): 15-32 [1858] +33-58 [1859]. Wien und Olmüz: E. Hölzel.

Sulser, H. 2016. Die Brachiopoden der Klippendecke (Préalpes médianes) in den Préalpes romandes der Südwestschweiz, des Chablais und der zentralschweizerischen Klippen: eine Übersicht und paläogeographische Beziehungen. Revue de Paléobiologie 35(2): 385-416.

Thieuloy, J.-P. 1963. Nouveaux apports á la faune Tithonique du Col du Lauzon (Hautes-Alpes). Géologie Alpine 39: 283-302.

Toucas, A.M. 1890. Etude de la Faune des couches tithoniques de l'Ardéche. Bulletin de la Société géologique de France (Sér. 3) 18: 560-629.

Trauth, F. 1948. Die fazielle Ausbildung und Gliederung des Oberjura in den nördlichen Ostalpen. Verhandlungen der Geologischen Bundesanstalt 10-12: 145-218.

Vadász, E. 1935. Das Mecsek-Gebirge Geologische Beschreibung Ungarischer Landschaften I, 1-180 + xxv. Budapest: Königlich Ungarische Geologische Anstalt.

Vašíček, Z., J. Michalík, and D. Reháková. 1994. Early Cretaceous stratigraphy, palaeogeography and life in the Western Carpathians. Beringeria 10: 3-169.

Vogel, K. 1966. Eine funktionsmorphologische Studie an der Brachiopodengattung Pygope (Malm bis Unterkreide). Neues Jahrbuch für Geologie und Paläontologie, Abhandlungen 125: 423-442.

Vörös, A. 1993. Jurassic microplate movements and brachiopod migrations in the western part of the Tethys. Palaeogeography, Palaeoclimatology, Palaeoecology 100: 125-145.

Vörös, A. 1997. Jurassic brachiopods of Hungary. Faunal changes and paleobiogeography in the Western Tethys. Studia Naturalia 11: $1-110$. 
Vörös, A., and A. Dulai. 2007. Jurassic brachiopods of the Transdanubian Range (Hungary); stratigraphical distribution and diversity changes. Fragmenta Palaeontologica Hungarica 24-25: 51-68.

Waagen, W.H. 1883. Salt-Range fossils Volume I. Part 4. Productus Limestone fossils, Brachiopoda. Memoirs of the Geological Survey of India, Palaeontologia Indica (series 13) 2: 391-546.

Wein, Gy. 1961. A szerkezetalakulás mozzanatai és jellegei a KeletiMecsekben. A Magyar Állami Földtani Intézet Évkönyve 49(3): 759-768.

Wisniewska, M. 1932. Les Rhynchonellidés du Jurassique sup. de Pologne. Palaeontologia Polonica 2(1): viii + 1-71.
Williams, A., S. Carlson, C.H.C. Brunton, L.E. Holmer, and L.E. Popov. 1996. A supra-ordinal classification of the Brachiopoda. Philosophical Transactions of the Royal Society (B: Biological Sciences) 351: 1117-1193.

Zittel, K.A. 1870. Paleontologische Studien ueber die Grenzschichten der Jura- und Kreide-Formation im Gebiete der Karpathen, Alpen und Apenninen. II. Die Fauna der aeltern cephalopodenfuehrenden Tithonbildungen. Palaeontologische Mittheilungen aus dem Museum des Koeniglich-Bayerischen Staates 2: 119-309. 